\title{
Age-related macular degeneration associated polymorphism rs10490924 in ARMS2 results in deficiency of a complement activator
}

Sven Micklisch ${ }^{1 \dagger}$, Yuchen Lin $^{1 \dagger}$, Saskia Jacob ${ }^{2}$, Marcus Karlstetter ${ }^{3}$, Katharina Dannhausen $^{3}$, Prasad Dasari ${ }^{1}$, Monika von der Heide ${ }^{1}$, Hans-Martin Dahse ${ }^{1}$, Lisa Schmölz ${ }^{4}$, Felix Grassmann ${ }^{5}$, Medhanie Alene ${ }^{1}$, Sascha Fauser ${ }^{3}$, Harald Neumann ${ }^{6}$, Stefan Lorkowski ${ }^{4}$, Diana Pauly ${ }^{7}$, Bernhard H. Weber ${ }^{5}$, Antonia M. Joussen², Thomas Langmann ${ }^{3}$, Peter F. Zipfel ${ }^{1,8}$ and Christine Skerka ${ }^{1 *}$ (D)

\begin{abstract}
Background: Age-related macular degeneration (AMD) is the leading cause of blindness in developed countries. The polymorphism rs 10490924 in the ARMS2 gene is highly associated with AMD and linked to an indel mutation (del443ins54), the latter inducing mRNA instability. At present, the function of the ARMS2 protein, the exact cellular sources in the retina and the biological consequences of the rs10490924 polymorphism are unclear.

Methods: Recombinant ARMS2 was expressed in Pichia pastoris, and protein functions were studied regarding cell surface binding and complement activation in human serum using fluoresence-activated cell sorting (FACS) as well as laser scanning microscopy (LSM). Biolayer interferometry defined protein interactions. Furthermore, endogenous ARMS2 gene expression was studied in human blood derived monocytes and in human induced pluripotent stem cell-derived microglia (iPSdM) by PCR and LSM. The ARMS2 protein was localized in human genotyped retinal sections and in purified monocytes derived from AMD patients without the ARMS2 risk variant by LSM. ARMS2 expression in monocytes under oxidative stress was determined by Western blot analysis.
\end{abstract}

Results: Here, we demonstrate for the first time that ARMS2 functions as surface complement regulator. Recombinant ARMS2 binds to human apoptotic and necrotic cells and initiates complement activation by recruiting the complement activator properdin. ARMS2-properdin complexes augment C3b surface opsonization for phagocytosis. We also demonstrate for the first time expression of ARMS2 in human monocytes especially under oxidative stress and in microglia cells of the human retina. The ARMS2 protein is absent in monocytes and also in microglia cells, derived from patients homozygous for the ARMS2 AMD risk variant (rs10490924).

Conclusions: ARMS2 is likely involved in complement-mediated clearance of cellular debris. As AMD patients present with accumulated proteins and lipids on Bruch's membrane, ARMS2 protein deficiency due to the genetic risk variant might be involved in drusen formation.

\footnotetext{
* Correspondence: christine.skerka@hki-jena.de

${ }^{\dagger}$ Equal contributors

1 Department of Infection Biology, Leibniz Institute for Natural Product

Research and Infection Biology, Beutenbergstrasse 11, 07745 Jena, Germany

Full list of author information is available at the end of the article
} 


\section{Background}

Age-related macular degeneration (AMD) is a multifactorial disease and a prevalent cause of visual impairment in developed countries [1]. Genome-wide association studies revealed that variations in or near the complement genes $C F H$ [2-5], CFI [6], CFB [7], and C3 [8] are significantly associated with AMD. Thus, inappropriate complement activation and innate immunity are linked to the pathogenesis of AMD [1]. The complement system is a major part of innate immunity and plays an essential role in cellular homeostasis, tissue remodeling, as well as in host defense and inflammation $[9,10]$. Deregulated complement function or uncontrolled activation due to defective regulation has been implicated in AMD and other diseases including C3-glomerulopathy, paroxysmal nocturnal hemoglobinuria, and systemic lupus erythematosus [9-11].

In addition to mutations in complement genes, a polymorphism (rs10490924) in ARMS2 shows the highest association with AMD with an estimated relative risk of 8.1 for homozygous carriers [12-14]. The ARMS2 gene is present only in higher primates [15], and cellular expression and function of ARMS2 are widely unknown. Here, we focused on the role of ARMS2 in AMD pathophysiology and aimed at defining the functional consequences of the AMD associated polymorphism (rs10490924) in ARMS2. Our findings demonstrate ARMS2 expression in human monocytes and microglia cells and suggest that ARMS2 functions are directly linked to the complement system, thereby mediating the opsonization of apoptotic and necrotic cells.

\section{Methods}

\section{Patients}

The polymorphism in the ARMS2 gene, rs10490924 was described as highly associated with both forms of AMD leading to geographic atrophy (dry form) or neo-vascularization (wet form) [12, 13]. Patients diagnosed with the wet form of AMD according to the modified version of AMD study grading system (AREDS) as described previously by Spencer et al. [16] were genotyped for the polymorphisms in the ARMS2 gene rs2736911, rs10490924, and del443ins54 as described [2, 12]. Genomic DNA was extracted from $10 \mathrm{ml}$ whole blood cells of each patient using the PAX gene blood DNA kit (QiaGen). ARMS2 was amplified with primers (forward 5'TGTCACCACATTATGTCCC3' or 5'TGTCACTGCATTCCC TCCTGTCAT3' and reverse 5'GGCACCACTCCAGA ATTT3' or 5'AAGCTTCTTACCCTGACTTCCAGC3'), and the PCR products were separated by agarose gel electrophoresis, visualized under UV light and subsequently validated by bi-directional sequencing on an automated DNA sequencer (ABI/1130x, Applied Biosystems). According to the presence of the polymorphisms rs2736911, rs10490924, and del443ins54 in the ARMS2 gene, three groups of genotypes were created (homozygous without these polymorphisms (type I/I), heterozygous for rs1049 0924 and del443ins54 (type I/II), homozygous for rs1049 0924 and del443ins54 (type II/II), and homozygous for rs2736911 (type III/III).

\section{Human donor eyes}

Retinal samples of controls and AMD patients were obtained from the Center of Ophthalmology Eye Bank, University of Cologne. Retina 1: type I/I, craniocerebral injury, unknown hour postmortem, age 22. Retina 2: type I/I, intracranial bleeding, $27 \mathrm{~h}$ postmortem, age 82 . Retina 3: type I/I, hypoxia brain damage, $4.5 \mathrm{~h}$ postmortem, age 53. Retina 4: type II/II, exenteratio orbitae, $8 \mathrm{~h}$ postmortem, age 78 .

\section{Cells}

CHO-K1 Chinese ovary hamster cells (ATCC-CCL-61), pgsD-677 heparan sulfate deficient $\mathrm{CHO}$ cells (ATCC CRL2244), pgsA-745 xylosyltransferase 1 deficient $\mathrm{CHO}$ cells (ATCC CRL-2242), THP-1 human monocytes (ATCC TIB202), RAW264.7 Mouse leukemic macrophages (ATCC TIB-71), and native RPE cells (InnoProt) were all cultivated according to the costumer's advise. Human T cells, monocytes, and human erythrocytes were obtained from human blood samples of healthy volunteers. Human T cells, peripheral blood mononuclear cells (PBMCs), and erythrocytes were isolated with micro beads from Miltenyi Biotech, according to the manufacturer's protocol. Apoptosis of cells was induced by incubation of the cells with $0.4 \mu \mathrm{g} / \mathrm{ml}$ staurosporine for $24 \mathrm{~h}$ and necrosis by $1 \mathrm{~h}$ at $65{ }^{\circ} \mathrm{C}$. Apoptosis was confirmed by PI and annexin V-pacific blue positive staining (Life Technologies) using flow cytometry. Human microglia cell lines (iPSdM) were generated from induced pluripotent stem (iPS) cell lines obtained by reprogramming skin fibroblasts as previously described [17]. The cells proliferate without addition of growth factors, and they were passaged 1:3 twice a week. The microglia phenotype was confirmed by flow cytometry by expression of CD11b, CD11c, CD14, CD16, CD32, CD36, CD45, CD206, CX3CR1, and TREM2.

\section{ARMS2 gene expression (PCR)}

Cells (about $1 \times 10^{6}$ from each cell type) with or without stimulation by $400 \mathrm{ng}$ PMA LPS for $24 \mathrm{~h}$ or of $10 \mathrm{ml}$ whole blood were harvested and homogenized; total RNA was isolated using the PAX gene blood RNA kit (QiaGen). A 20 ng of isolated RNA was transcribed into cDNA using QuantiTect $^{\ominus}$ Reverse Transcription Kit (QiaGen). cDNA was amplified using Phusion PCR Kit (New England Biolabs), and primers situated in exon 1 (5'TCGGTGGTTCC TGTGTCCTTCATT3') and exon 2 (5'TCACCTTGCTG CAGTGTGGATGAT3') of ARMS2 or for amplification 
of actin (forward 5'ACCAACTGGGACGACAT3'; reverse 5'CTAGAAGCATTTGCGGTG3'). Synthesis was performed by denaturing for $60 \mathrm{~s}$ at $96^{\circ} \mathrm{C}$ followed by annealing for $30 \mathrm{~s}$ at $69{ }^{\circ} \mathrm{C}\left(\right.$ ARMS2) or $60{ }^{\circ} \mathrm{C}$ (actin) and synthesis for $60 \mathrm{~s}$ (ARMS2) or $120 \mathrm{~s}$ (actin) at $72{ }^{\circ} \mathrm{C}$ for 35 cycles. Extension was performed for $480 \mathrm{~s}$ at $72{ }^{\circ} \mathrm{C}$. Amplified PCR products were separated in agarose and visualized under UV light. Bands were excised, purified, and sequenced on an automated DNA sequencer (ABI/1130x, Applied Biosystems). Sequences were aligned to ARMS2 genomic sequences (NM_001099667).

\section{Expression and purification of recombinant ARMS2}

ARMS2 was recombinant expressed using the Pichia pastoris expression system. The expression vector $p P I C Z B$ contained codon usage optimized full length cDNA of the ARMS2 gene coupled to a myc and $6 \times$ histidine coding tag for purification (Life Technologies) (Additional file 1: Figure S1). $P$. pastoris cells (strain X33) were transformed with the recombinant expression vector, and ARMS2 expressing clones were selected via zeocin containing selection medium according to the standard protocols. Expressed His-tagged proteins were purified by $\mathrm{Ni}^{2+}$-chelate affinity chromatography from the cells $[18,19]$. Cell lyses were performed in binding buffer $\left(10 \mathrm{mM} \mathrm{Na}_{2} \mathrm{HPO}_{4}\right.$, $10 \mathrm{mM} \mathrm{NaH} \mathrm{PO}_{4}, 10 \mathrm{mM}$ imidazol, $1 \mathrm{M} \mathrm{NaCl}, 2 \%(v / v)$ Nonidet P-40, 20\% $(v / v)$ glycerol; pH 7.0) together with glass beads (Roth) by FastPrep ${ }^{\oplus}-24$ (MP Biomedicals) at $4 \mathrm{~m} / \mathrm{s}$ for $60 \mathrm{~s}$. Protease activity was inhibited by addition of complete EDTA-free (Roche). Protein was eluted from HisTrap $^{\text {TM }}$ HP column (GE Healthcare) using elution buffer (10 mM Na $2 \mathrm{HPO}_{4}, 10 \mathrm{mM} \mathrm{NaH} \mathrm{PO}_{4}, 500 \mathrm{mM}$ imidazol, $500 \mathrm{mM} \mathrm{NaCl} ; \mathrm{pH}$ 7.0). Purified ARMS2 was concentrated in storage buffer $\left(10 \mathrm{mM} \mathrm{Na} \mathrm{HPO}_{4}, 10 \mathrm{mM}\right.$ $\mathrm{NaH}_{2} \mathrm{PO}_{4}, 500 \mathrm{mM} \mathrm{NaCl} ; \mathrm{pH}$ 7.0). In addition to the recombinant protein, three ARMS2 peptides were generated. Peptide 1 included amino acids 1 to 40, peptide 2 amino acids 41 to 70, and peptide 3 amino acids 71 to 107 (Jerini Peptide Biotechnologies). Polyclonal ARMS2 antiserum was generated by immunization of rabbits with the here described recombinant ARMS2 protein expressed in P. pastoris (Davids Biotechnologies). Generated ARMS2 antiserum (ARMS2 $2_{\text {Jena }}$ ) was purified with HiTrap Protein A HP $1 \mathrm{ml}$ column (GE Healthcare) and the major epitope of these antibodies determined by pepspot analysis. Peptides of ARMS2 (33 peptides of 13 amino acids with three amino acids overlap) were spotted to a membrane (Jerini Peptide Technologies), incubated with the antiserum and secondary anti-rabbit antibodies for detection. Polyclonal rabbit antiserum generated to the N-terminus of ARMS2 (ARMS2 $2_{\text {com }}$ ) was purchased from CovaLab. In addition, a mouse monoclonal antibody was generated to the C-terminal peptide 3 of ARMS2 (aa 71-107 =
IHTELCLPAFFSPAGTQRRFQQPQHHLTLSIIHTAAR) (ARMS2 $2_{\mathrm{mAb}}$ ) by standard methods.

Recombinant ARMS2 was separated by SDS-PAGE under reducing conditions (50 mM TRIS-HCL, 1.6\% ( $w / v)$ SDS, 7\% (v/v) glycerol, 8 M UREA, 4\% (v/v) $\beta$ mercaptoethanol, $0.016 \%(w / v)$ bromophenol blue; $\mathrm{pH} 6.8)$ and visualized either by silver staining or immune-blotting using $\mathrm{ARMS} 2_{\text {com }}, \mathrm{ARMS} 2_{\text {Jena }}$ antiserum, or mouse $\alpha$ Penta-His monoclonal antibodies (QiaGen). Mass of whole deglycosylated recombinant ARMS2 was determined by mass spectrometry. To remove the carbohydrate side chains from recombinant ARMS2 $(10 \mu \mathrm{g})$, the protein was incubated with 0.5 units of PNGase (Roche) for $3 \mathrm{~h}$ at $37^{\circ}$ $\mathrm{C}$ or the purification tag was cleaved off by enterokinase (New England Biolabs) overnight at RT and repurified with a His'Trap $^{\text {тм }}$ HP column.

For immunoprecipitation, monoclonal $\alpha$-ARMS2 antibody $(20 \mu \mathrm{g})$ was loaded onto Protein G Magnetic beads (New England BioLabs) for $1 \mathrm{~h}$ at $4{ }^{\circ} \mathrm{C}$ in binding buffer (20 mM sodium phosphate buffer, pH 7.0). THP-1 cells $\left(1 \times 10^{7}\right)$ were lysed in $1 \mathrm{ml}$ lysis buffer $(150 \mathrm{mM} \mathrm{NaCl}$, 1\% NP-40, 25 nM Tris- $\mathrm{HCl}, 1$ mM EDTA, 5\% glycerol) containing $1 \mathrm{mM}$ PMSF, centrifuged at 16,000 $\mathrm{g}$ for $10 \mathrm{~min}$ at $4{ }^{\circ} \mathrm{C}$, added to the antibody-loaded beads and incubated on a rotating shaker overnight at $4{ }^{\circ} \mathrm{C}$. After removal of the supernatant, the beads were washed and proteins were eluted from the beads in $30 \mu$ of elution buffer (0.1 M glycine, $\mathrm{pH} 2.7$ ). The eluted proteins were evaluated for the presence of ARMS2 by SDS-PAGE and mass spectrometry. To show endogenous ARMS2 expression, monocytes were isolated from fresh blood and about $1 \times$ $10^{6}$ cells were stressed by addition of $\mathrm{H}_{2} \mathrm{O}_{2}(0.001-1 \mathrm{mM})$ for $1 \mathrm{~h}$. Supernatants were replaced by cell culture medium, and cells were incubated for $20 \mathrm{~h}$. Cells were lysed in buffer (50 mM TRIS-HCL, 1.6\% (w/v) SDS, 7\% $(v / v)$ glycerol, $8 \mathrm{M}$ UREA, 4\% ( $/ / v) \beta$-mercaptoethanol, $0.016 \%(w / v)$ bromophenol blue; $\mathrm{pH} 6.8)$, centrifuged and supernatants were separated by SDS PAGE, blotted to a membrane and ARMS2 detected with $\alpha \mathrm{ARMS} 2_{\text {Jena. }}$

\section{Mass spectrometry}

Recombinant ARMS2 or immunoprecipitated ARMS2 from THP-1 cells were separated by SDS-PAGE and stained with coomassie blue. Protein bands were excised from the gel and washed repeatedly in water and $50 \mathrm{mM}$ $\mathrm{NH}_{4} \mathrm{HCO}_{3}$ /acetonitrile $1+1(v / v)$ for $15 \mathrm{~min}$. Gel pieces in acetonitrile were dried by vacuum centrifugation. Gel pieces were soaked in $50 \mathrm{mM} \mathrm{NH} \mathrm{HCO}_{3}$ with $10 \mathrm{mM}$ DTT for $45 \mathrm{~min}$ at $56{ }^{\circ} \mathrm{C}$ followed by alkylation $(50 \mathrm{mM}$ iodoacetamide in $50 \mathrm{mM} \mathrm{NH} \mathrm{NCO}_{3}$ for $30 \mathrm{~min}$ in the dark). Upon washing in $50 \mathrm{mM} \mathrm{NH}_{4} \mathrm{HCO}_{3}$ /acetonitrile, gel pieces were incubated in trypsin digestion buffer $(20 \mathrm{ng} / \mu \mathrm{l}$ trypsin in $25 \mathrm{mM} \mathrm{NH}_{4} \mathrm{HCO}_{3}$ ) overnight at $37{ }^{\circ} \mathrm{C}$. The peptides were extracted from the gel plugs by incubation in 
acetonitrile/trifluoroacetic acid $1+1(v / v)$ for $30 \mathrm{~min}$ at RT. Extracted peptides $(1 \mu \mathrm{l})$ were premixed with the same volume of the matrix $\alpha$-CHCA solution and spotted on a matrix-assisted laser desorption ionization (MALDI) plate. Mass was analyzed using MALDI TOF-mass spectrometer (UltrafleXtreme, Bruker Daltonics, Germany) in the reflector mode with appropriate $m / z$ range and laser intensity. For analysis of the whole ARMS2 protein, the recombinant protein was deglycosylated and untagged as described above. Analysis of the protein, the instrument was utilized in linear mode. Data analysis was performed with current NCBInr database using Mascot search with a peptide mass tolerance of $100 \mathrm{ppm}$. The analysis was repeated three times.

\section{Detection of endogenous ARMS2 by LSM microscopy}

For detection of endogenous ARMS2 protein, monocytes of seven ARMS2 genotyped individuals (two (I/I), one (I/ II), two (II/II) one (III/III)) were isolated from PBMCs derived from 20 to $40 \mathrm{ml}$ human blood samples. Blood samples were diluted 1:1 in PBS and overlaid with $15 \mathrm{ml}$ Ficoll. After centrifugation at $1600 \mathrm{rpm}$ for $20 \mathrm{~min}$, PBMCs were collected and washed in $10 \mathrm{ml}$ PBS. Monocytes were isolated from PBMCs using a Percoll gradient (3 ml of PBMCs were overlaid by $6 \mathrm{ml}$ of $54 \%$ Percoll) centrifuged as above, harvested, and washed in ice-cold PBS. Cells $\left(1 \times 10^{6}\right)$ were transferred into a 4-well slide chamber $\left(\mathrm{Lab}^{\mathrm{T}} \mathrm{Tek}^{\circ}\right)$ and stained for laser scanning microscopy as previously described [19]. Briefly, isolated monocytes or THP-1 cells in chamber slides were fixed with paraformaldehyde ( $3 \%$ at RT for $15 \mathrm{~min}$ ) permeabilized in Triton X-100 (0.3\%) (Roth) 5 min on ice, blocked with FcR blocking reagent (Miltenyi) $10 \mathrm{~min}$ at $4{ }^{\circ} \mathrm{C}$ and stained with polyclonal rabbit ARMS2 antiserum ( $\alpha$ ARMS2 $\left.2_{\text {Jena }}\right)(1: 200)$, monoclonal ARMS2 antibodies $\left(\alpha A R M S 2_{m A b}\right)$ (1:200) followed by incubation with Alexa-647 labeled anti-rabbit or anti-mouse (1:400) for $1 \mathrm{~h}$ at RT. DNA was stained with DAPI $(10 \mu \mathrm{g} / \mathrm{ml})$ for $15 \mathrm{~min}$ at RT. After washing, the samples were examined by LSM (LSM 510, Carl Zeiss, Jena).

CHO-K1 cells $\left(\sim 1 \times 10^{5}\right)$ were incubated with $10 \mu \mathrm{g}$ ARMS2 and properdin, either alone or together. After $1 \mathrm{~h}$, cells were washed and placed on a chamber slide (Nunc). After $1 \mathrm{~h}$, adherent cells were fixed with $3 \%$ paraformaldehyde for $15 \mathrm{~min}$. CHO surface-bound ARMS2 was visualized using rabbit ARMS2 antiserum (1:100) and Alexa-488 conjugated secondary antibody (1:200; Life Technologies) in assay buffer (1\% BSA in RPMI media). Properdin was detected by mouse monoclonal properdin antibody (1:100; QuiDel) and secondary Alexa-647 conjugated antibody (1:200; Life Technologies) in assay buffer. DAPI (Sigma) was used to stain DNA. Images were taken by LSM 710 Meta (Zeiss) and co-localization was analyzed with Zen 2009 software (Zeiss). All incubation steps were done in RPMI media at RT.

\section{Histology}

Eyes were soaked in phosphate buffered saline (PBS) containing $4 \%$ formaldehyde followed by punching of a tissue strip ranging from the optic nerve to the fovea/parafovea which was then processed for paraffin embedding. Sections of $12 \mu \mathrm{m}$ thickness derived from 2 genotyped individuals (genotype (I/I) and (II/II)) were obtained and subjected to immunohistochemical staining. After de-paraffinization by a series of graded ethanol slides were placed in a $97{ }^{\circ} \mathrm{C}$ hot water bath in antigen retrieval buffer $(0.05 \mathrm{M}$ Tris buffered saline, $0.05 \%$ Tween-20, $\mathrm{pH}$ 9.0) for $20 \mathrm{~min}$. Slides were then washed with $1 \%$ goat serum in $1 x$ PBS-T (PBS with $0.4 \%$ Triton-X) for $10 \mathrm{~min}$ for two times. To prevent unspecific binding, sections were covered with blocking buffer ( $5 \%$ goat serum in $1 \mathrm{xPBS}-\mathrm{T}$ ) in a humidified chamber and incubated for $30 \mathrm{~min}$ at room temperature. Primary antibodies included anti-ARMS2 (1:200, rabbit polyclonal), anti-CD68 (1:200, monoclonal rat anti-mouse, AbDSerotec), and anti-CD68 (1:200, monoclonal mouse antihuman, Dako). Primary antibodies were incubated overnight at $4{ }^{\circ} \mathrm{C}$. After the two washing steps with $1 \%$ serum PBS-T, sections were incubated with labeled secondary antibodies coupled to Alexa-488 (green) or Alexa594 (red) (Jackson ImmunoResearch, West Grove, PA, USA). Retinal nuclei were counter-stained with DAPI and mounted in DAKO fluorescent mounting medium (Dako Deutschland GmbH, Hamburg, Germany) and analyzed on an Axioskop 2 MOT plus Apotome microscope (Zeiss, Jena, Germany).

\section{Binding analyses ELISA}

ARMS2 binding to complement proteins $\mathrm{C} 3, \mathrm{C} 3 \mathrm{~b}$, C3c, C3d, iC3b, factor B, properdin (all Complement Technologies) and human serum albumin (HSA) (Nutritional Biochemicals) (each $500 \mathrm{ng}$ in PBS) were coated onto MediSorp microtiter plates (Nunc) over night at $4{ }^{\circ} \mathrm{C}$. Wells were blocked with buffer I (AppliChem) for $2 \mathrm{~h}$ at RT and incubated with $500 \mathrm{ng}$ ARMS2 in assay buffer $(2 \%(w / v)$ BSA, $0.05 \%(v / v)$ Tween-20 in PBS) for $1 \mathrm{~h}$ at RT. ARMS2 was detected with ARMS2 antiserum diluted 1:1000 and a secondary HRP conjugated antibody 1:2000 in CrossDown buffer (AppliChem) at $492 \mathrm{~nm}$.

Properdin binding to ARMS2 Recombinant ARMS2 or HSA (each $500 \mathrm{ng}$ in PBS) was coated onto MaxiSorp microtiter plates (Nunc) over night at $4{ }^{\circ} \mathrm{C}$. Wells were then washed with $\mathrm{PBS}+0.05 \%(v / v) \quad$ Tween-20 and blocking was performed with blocking buffer $(5 \%(w / v)$ BSA, $0.05 \%(v / v)$ Tween-20 in PBS) for $2 \mathrm{~h}$ at RT. After another washing step, wells were incubated with increasing amounts of properdin (12.5-100 nM) in assay buffer 
$(2 \%(w / v)$ BSA, $0.05 \%(v / v)$ Tween-20 in PBS). After incubation for $1 \mathrm{~h}$ at RT, wells were washed and bound properdin was detected with a goat properdin antiserum diluted 1:2000 and a secondary horse radish peroxidate (HRP)-conjugated antibody diluted 1:2000 in assay buffer. Multiscan Ascent ELISA Reader measured absorption at $492 \mathrm{~nm}$. To determine the interaction domain in ARMS2 responsible for properdin binding to ARMS2, peptide 1 , peptide 2 , and peptide 3 (each $500 \mathrm{nM}$ ) were coated to the microtiter plate, incubated with $2 \mu \mathrm{M}$ properdin (TECOmedical $\mathrm{GmbH}$ ) in PBS and binding of properdin was detected as described before. Primary monoclonal properdin antibody (1:1000) [20] and secondary anti mouse 1:2000 (Dako, Denmark) were used for detection.

The binding affinity of properdin to ARMS2 was measured using biolayer interferometry on a BLITZ system (Forte Bio). His-tagged ARMS2 was loaded onto $\mathrm{Ni}^{2+}$ NTA biosensors (Forte Bio) in assay buffer (PBS (Lonza) with $0.1 \%(m / v)$ gelatin). Loaded biosensors were blocked using assay buffer with $10 \mu \mathrm{g} / \mathrm{ml}$ biocytin (Sigma-Aldrich) for $60 \mathrm{~s}$. After washing, the biosensors were dipped in 4- $\mu$ l properdin solution with concentrations varying from 70 to $1800 \mathrm{nM}$ properdin. The $k_{\mathrm{D}}$ was determined by fitting data to a 1:1 model algorithm with the BLITZ software.

Recruitment of C3b by ARMS2 bound properdin Properdin $(100 \mathrm{nM})$ was bound to immobilized recombinant ARMS2 as described before. Wells were washed with assay buffer $(2 \%(w / v)$ BSA, $0.05 \%(v / v)$ Tween-20 in PBS) and incubated with increasing amounts of $\mathrm{C} 3 \mathrm{~b}$ (4-12 $\mathrm{nM}$ ) in assay buffer for $1 \mathrm{~h}$ at RT. Unbound C3b was removed by additional wash steps, and binding was detected at $492 \mathrm{~nm}$ by mouse C3d monoclonal antibody (1:2000, Quidel) and secondary HRP-conjugated antibody (1:2000) in assay buffer.

Ba activities ARMS2 (500 nM) was incubated with 20\% NHS in $\mathrm{Mg}^{2+}$ EGTA buffer $(1 \%(w / v)$ BSA, $20 \mathrm{mM}$ HEPES, $144 \mathrm{mM} \mathrm{NaCl}, 7 \mathrm{mM} \mathrm{MgCl}_{2}, 10 \mathrm{mM}$ EGTA, $\mathrm{pH}$ 7.4) for $15 \mathrm{~min}$ at $37^{\circ} \mathrm{C}$. The generated Ba product was analyzed at $540 \mathrm{~nm}$ using a Ba MicroVUE ELISA Kit (QuiDel).

\section{Flow cytometry}

All fluoresence-activated cell sorting (FACS) analyses were performed with a LSR II flow cytometer (BD Science); 10,000 cells were evaluated and data were calculated using FlowJo Software (Tree Star).

ARMS2 deposition CHO-K1, pgsD-677, pgsA-745 (each $\left.1 \times 10^{6}\right)$, native RPE $\left(1 \times 10^{5}\right)$, human erythrocytes $\left(\right.$ each $\left.1 \times 10^{7}\right)$ as well as isolated naive $\mathrm{T}$ cells $\left(1 \times 10^{6}\right)$ were incubated with increasing amounts of ARMS2 (10$500 \mathrm{nM})$ in assay buffer $(1 \%(w / v)$ BSA in PBS) for $1 \mathrm{~h}$ on ice. ARMS2 binding was detected with rabbit ARMS2 antiserum (1:200) and an Alexa-647 conjugated antibody (Life Technologies) (1:400). Similarly, factor H (10$500 \mathrm{nM}$, Comptech) was bound to $\mathrm{CHO}-\mathrm{K} 1$ cells.

Heparan sulfate competition assay Recombinant ARMS2 (500 nM) was incubated with $1 \times 10^{7}$ heparin coated beads (GE Healthcare) and increasing amounts of heparan sulfate (0-12 mM, Sigma) in assay buffer (1\% ( $w /$ v) BSA in PBS) for $1 \mathrm{~h}$ on ice. ARMS2 binding was detected with rabbit ARMS2 antiserum 1:200 and Alexa-647 conjugated antibodies (Life Technologies) 1:400. Factor $\mathrm{H}$ (500 nM, Comptech) was incubated with the beads and detected with factor $\mathrm{H}$ antiserum (Comptech).

C3b deposition Complement activation assays were performed as previously described [19]. CHO-K1 and pgsA-745 (each $1 \times 10^{6}$ ) were incubated in $20 \%$ NHS, or heat-inactivated $20 \%$ NHS (hiNHS) $\left(30 \mathrm{~min}\right.$ at $56{ }^{\circ} \mathrm{C}$ ) forms healthy human donors in $\mathrm{Mg}^{2+}$ EGTA buffer (1\% $(w / v)$ BSA, $20 \mathrm{mM}$ HEPES, $144 \mathrm{mM} \mathrm{NaCl}, 7 \mathrm{mM}$ $\mathrm{MgCl}_{2}, 10 \mathrm{mM}$ EGTA, pH 7.4) for $45 \mathrm{~min}$ at $37^{\circ} \mathrm{C}$. C3b deposition was determined by flow cytometry using mouse $\alpha$-C3b monoclonal antibody (FitzGerald) diluted 1:100 and secondary Alexa-647 conjugated antibodies (Life Technologies) diluted 1:200 in $\mathrm{Mg}^{2+}$ EGTA buffer for $1 \mathrm{~h}$ on ice. Deposition was normalized and NHS alone defined as $100 \%$. Influence of ARMS2, factor $\mathrm{H}$ (CompTech), or HSA (Nutritional Biochemicals) on C3b deposition was evaluated, after preincubation of either cells $\left(1 \mathrm{~h}\right.$ on ice) or serum $\left(15 \mathrm{~min}\right.$ at $\left.37{ }^{\circ} \mathrm{C}\right)$ with increasing amounts of each protein (100 to $750 \mathrm{nM}$ ).

Properdin deposition $\mathrm{CHO}-\mathrm{K} 1$ cells $\left(1 \times 10^{6}\right)$ were preincubated with $500 \mathrm{nM}$ ARMS2 for $1 \mathrm{~h}$ on ice. Washed cells were incubated either in 20\% NHS diluted with $\mathrm{Mg}^{2+}$ EGTA buffer (1\% $(w / v)$ BSA, $20 \mathrm{mM}$ HEPES, $144 \mathrm{mM} \mathrm{NaCl}, 7 \mathrm{mM} \mathrm{MgCl}$, $10 \mathrm{mM}$ EGTA, pH 7.4) or EDTA buffer $(1 \%(w / v)$ BSA, $20 \mathrm{mM}$ HEPES, $144 \mathrm{mM}$ $\mathrm{NaCl}, 10 \mathrm{mM}$ EDTA, $\mathrm{pH} 7.4$ ) for $45 \mathrm{~min}$ at $37{ }^{\circ} \mathrm{C}$ or with $100 \mathrm{nM}$ purified properdin (CompTech) in PBS containing 1\% BSA for $1 \mathrm{~h}$ at RT. Properdin deposition was analyzed by flow cytometry using a properdin monoclonal antibody (QuiDel) (1:200) followed by an Alexa-647 conjugated antibody (Life Technologies) (1:400).

\section{Statistical analysis}

Significant differences between two groups were analyzed using the Student's two-tailed $t$ test. Values of " $p<0.05, * * p<0.01, * * * 0<0.001$ were considered statistically significant. 


\section{Results}

Human monocytes and iPS-derived microglia cells express ARMS2

A typical hallmark of AMD is the accumulation of cellular material in the form of drusen in the macular region of the retina [1]. Normally, microglia cells, the resident macrophages of the retina, take up modified or dead cells by phagocytosis and the uptake of C3b opsonized cellular debris is markedly enhanced [21, 22]. Since infiltration of inflammatory monocytes is reported in AMD retinas [23], we first asked whether monocytes express ARMS2 and determined ARMS2 mRNA expression in these cells. A specific RT-PCR amplicon was generated with cDNA derived from the human monocytic THP-1 cells and also from human primary monocytes (Fig. 1a). DNA sequencing confirmed that this amplicon represented ARMS2 (data not shown), thus demonstrating expression of ARMS2 in human monocytes. Next, we analyzed whether microglia cells, the resident immune cells of the brain and the retina, [24] express ARMS2 transcripts. To circumvent the viability problems with human postmortem microglia, ARMS2 transcription was analyzed in microglia cells derived from human induced pluripotent stem cells (iPSdM) [17]. Using the same ARMS2 specific primers as before, a specific ARMS2 amplicon was generated with microglia-derived cDNA (Fig. 1a). ARMS2 expression was previously shown in the retina, placenta, and whole blood [2, 12, 25]. Here, we additionally identified ARMS2 gene expression in human blood monocytes and microglia cells.

\section{Expression of recombinant ARMS2 and generation of antibodies}

To detect the endogenous ARMS2 protein in monocytes, a new polyclonal rabbit ARMS2 antiserum was raised against a recombinant histidine-tagged ARMS2 protein expressed in $P$. pastoris. The polyclonal antiserum was characterized by the identification of the main epitope in ARMS2 bound by the antibodies. Therefore, 33 ARMS2 peptides each 13 amino acid long and with an overlap of three amino acids were spotted to a membrane and subsequently stained with the polyclonal ARMS2 antiserum. The antibodies bound predominantly to the C-terminal end of ARMS2 (Fig. 1b). When separated by SDS-PAGE under reducing conditions, recombinant ARMS2 appeared with mobilities of 17 and $15 \mathrm{kDa}$ by immune staining using the new antiserum and also with a commercial ARMS2 antiserum or a Histag mAb (Fig. 1c). The $17 \mathrm{kDa}$ protein band was cut out, deglycosylated, digested by trypsin, and then analyzed by mass spectrometry. All peptides derived from the $17 \mathrm{kDa}$ band covered regions (95\%) of ARMS2. MS of the untagged, deglycosylated protein revealed a dominant protein peak with a mass of 11.349 Da.

\section{Monocytes derived from AMD patients with the ARMS2 risk haplotype lack the ARMS2 protein}

The ARMS2 risk variant is defined by the polymorphism rs10490924, which is linked to an indel mutation (del443ins54) in the $3^{\prime}$ untranslated region of the $A R M S 2$ gene [12]. The ARMS2 indel mutation is considered to lead to ARMS2 mRNA instability, as this mutation deletes the poly $A$ signal and integrates two AUUUA motifs that mediate rapid mRNA turnover. To determine whether this ARMS2 risk variant (rs10490924 with del443ins54) affects ARMS2 expression, we determined $A R M S 2$ expression on the protein level in peripheral blood monocytes isolated from genotyped AMD patients. Monocytes of three different genotypes were compared as follows: type I/I harbors two non-risk alleles of $A R M S 2$. type I/II has one ARMS2 risk allele (rs10490924 with del443ins54) and a non-risk allele, and type III has two alleles of the ARMS2 risk variants (rs10490924 with del443ins54). Blood monocytes of the three genotypes were isolated from AMD patients, fixed in chamber slides, permeabilized, and stained with ARMS2 antiserum and with a monoclonal ARMS2 antibody. The ARMS2 protein was identified in the cytoplasm of monocytes harboring one or two alleles of the ARMS2 non-risk variant (i.e., type I/I or I/II) (Fig. 1d). In contrast, monocytes derived from the three patients with two risk alleles (II/II) showed no ARMS2 protein staining (Fig. 1c). Also, monocytes derived from a single patient homozygous with an ARMS2 stop mutation (rs2736911, genotype III/III) lacked the ARMS2 signal. To verify ARMS2 presence in the monocytes, ARMS2 was also stained in monocytic cells THP-1 using polyclonal antiserum $\left(\alpha A R M S 2_{\text {Jena }}\right)$. Again, single spots were detected in the cytoplasm of the cells (Fig. 1d). In contrast, macrophages of murine origin lacked an ARMS2 signal. As the signal of ARMS2 in monocytes was very weak, we tested whether ARMS2 expression is enhanced under stress signals. Therefore, human blood monocytes were challenged for $1 \mathrm{~h}$ with $\mathrm{H}_{2} \mathrm{O}_{2}$ and grown over night and lysates investigated for ARMS2 expression by Western blot analysis. Interestingly, ARMS2 expression increased in monocytes upon oxidative stress (Fig. 1e). Having shown that ARMS2 is expressed in THP-1 cells, immunoprecipitation was performed combined with mass spectrometry to detect the endogenous ARMS2 protein. A new generated monoclonal ARMS2 antibody was bound to a protein G column, incubated with THP1 whole cell lysate, washed and antibody bound proteins were eluted from the column. After separation via SDS PAGE and coomassie blue staining, single bands were extracted from the gel (Fig. 1f). Mass spectrometry revealed ARMS2 peptides in the cell lysate of THP-1 cells (Fig. 1f) and in probes derived from precipitated recombinant ARMS2 (not shown). Altogether, the results 

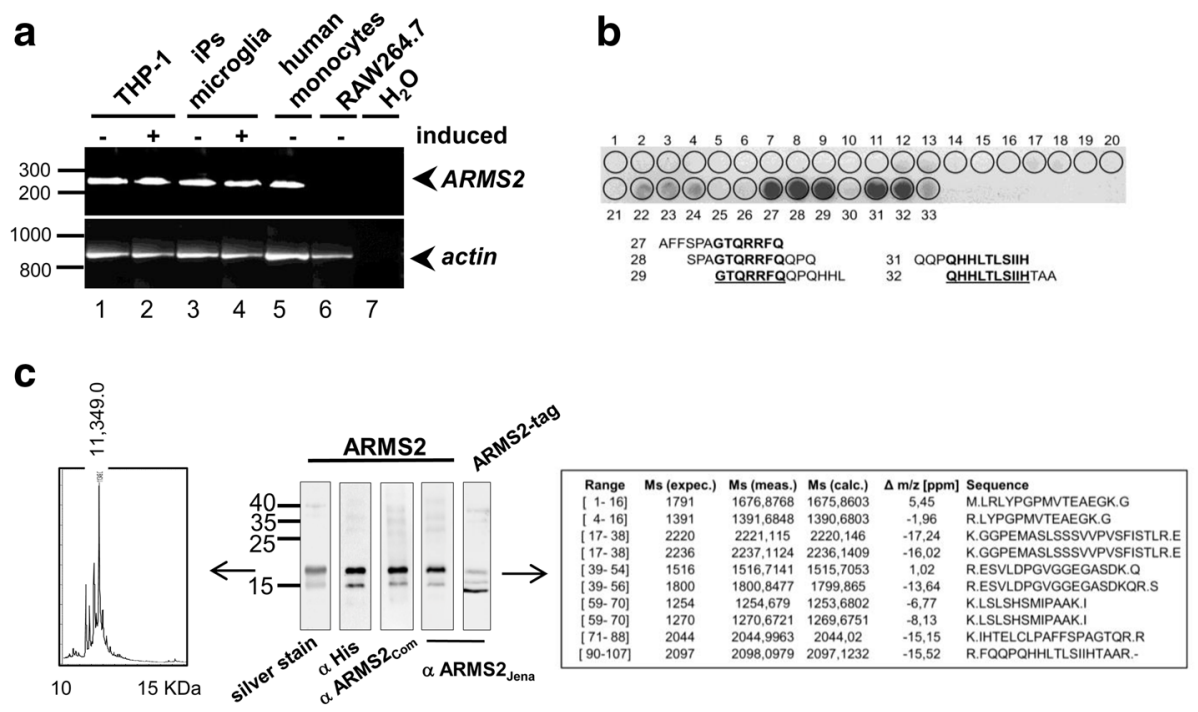

d blood monocytes

\section{e}
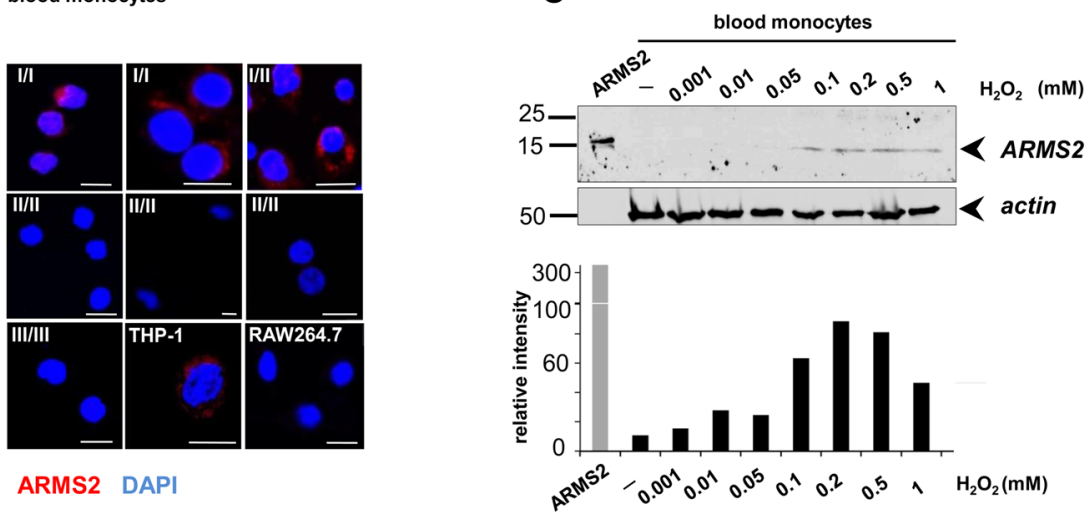

ARMS2 DAPI

$\mathbf{f}$

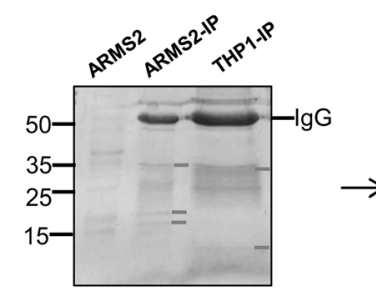

\begin{tabular}{|c|c|c|c|c|c|}
\hline 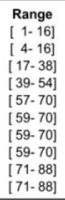 & $\begin{array}{c}\text { Ms (expec.) } \\
1791 \\
1407 \\
2220 \\
1516 \\
1485 \\
1254 \\
1254 \\
1270 \\
2044 \\
2044\end{array}$ & $\begin{array}{l}\text { Ms (meas.) } \\
1791,793 \\
1407,798 \\
2221,043 \\
1510.751 \\
1485,677 \\
1254,721 \\
1254,738 \\
1270,742 \\
2045,027 \\
2045,024\end{array}$ & 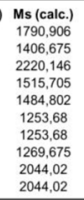 & 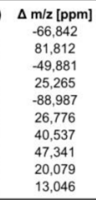 & 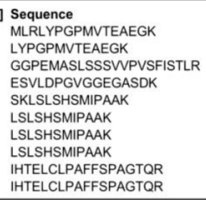 \\
\hline
\end{tabular}

Fig. 1 ARMS2 expression in human monocytes and microglia cells. a Transcription of ARMS2 in uninduced or PMA (400 ng, 24 h) induced THP-1 monocytes, mouse RAW 264.7 cells, microglial cells stimulated with LPS $(5 \mathrm{ng} / \mathrm{ml}, 24 \mathrm{~h}$ ) or blood-derived human monocytes. b New polyclonal antiserum generated to recombinant ARMS2 detects the C-terminal part of ARMS2 as indicated by the dark spots. Peptides of ARMS2 (33 amino acids with an overlap of 3 amino acids) were spotted to a membrane and incubated with the ARMS2 antiserum. c Recombinant ARMS2 expressed in P. pastoris and purified by $\mathrm{Ni}^{2+}$ chromatography appears as monomeric protein of about $\sim 15 / 17 \mathrm{kDa}$ identified by silver staining or Western blot analysis using either monoclonal penta-Histidin, purchased polyclonal ARMS2 antiserum (AARMS2 $\mathrm{com}$ ) or polyclonal ARMS2 antiserum (aARMS2 Jena), generated to the recombinant protein) as indicated. The ARMS2 protein without purification tag showed a mobility of about $11 \mathrm{kDa}$. Mass spectrometry of the deglycosylated $17 \mathrm{kDa}$ ARMS2 band revealed ARMS2 peptides (raw data). MS of the whole protein showed a protein with a mass of $11.349 \mathrm{kDa}$. $\mathbf{d}$ ARMS2 is present in monocytes with one or two copies of the non-risk ARMS2 variant, but is absent in cells with the homozygous rs10490924 (II/II) or rs2736911 (II//II) polymorphism. ARMS2 is detected in the cytoplasm of THP-1 cells (1/II), but ARMS2 is absent in RAW264.7. cells. Cells in (d) were permeabilized, stained for ARMS2 (red) or DNA (blue) and visualized by laser scanning microscopy. Scale bar $=10 \mu \mathrm{m}$. e Blood-derived monocytes express ARMS2 upon oxidative stress. Cells were incubated for $1 \mathrm{~h}$ in medium with $\mathrm{H}_{2} \mathrm{O}_{2}(0.001-1 \mathrm{mM})$, for another $20 \mathrm{~h}$ in normal medium, lysed in loading buffer, and proteins were separated by SDSPAGE and immunoblotted using aARMS2 Jena. Densitometric analysis is shown in the graph below. The same blot was also stained for $\beta$-actin as a loading control. f Immunoprecipitation of ARMS2 from THP-1 cell lysate $\left(1 \times 10^{7}\right)$ with new monoclonal ARMS2 antibodies. Eluted proteins were separated by SDS-PAGE, stained with coomassie blue and single bands (white bars) investigated by mass spectrometry. ARMS2 peptides from five immunoprecipitations are shown. Precipitation of recombinant ARMS2 revealed ARMS2 petptides (data not shown). Experiments shown in a to e are representatives of three independent experiments. $\triangle \mathrm{m} / \mathrm{z}[\mathrm{ppm}]$ mass tolerance, ARMS2-IP imunoprecipitation of recombinant ARMS2, THP1-IP ARMS2 immunoprecipitated from THP-1 cells 
demonstrate for the first time ARMS2 protein expression in monocytes and that the risk variants of ARMS2 lead to ARMS2 deficiency in these cells.

We next analyzed ARMS2 expression and localization in retinal tissue and tried to identify the responsible cells in the human retina, which express the protein. To this end, retinal tissue cross sections from genotyped individuals were analyzed by histology using the new ARMS2 antiserum. ARMS2 was identified in stained cross sections of the retina derived from individuals with the I/I genotype (Fig. 2A, B I-IV), but ARMS2 was not detectable in sections of the II/II genotype (one representative of three stainings is shown, Fig. 2B IX, X). ARMS2 immunoreactivity appeared in the inner retinal layer as a speckled pattern and was also seen in the choroid (Fig. 2A, B V-VIII), which is in agreement with the presence of ARMS2 in monocytes.

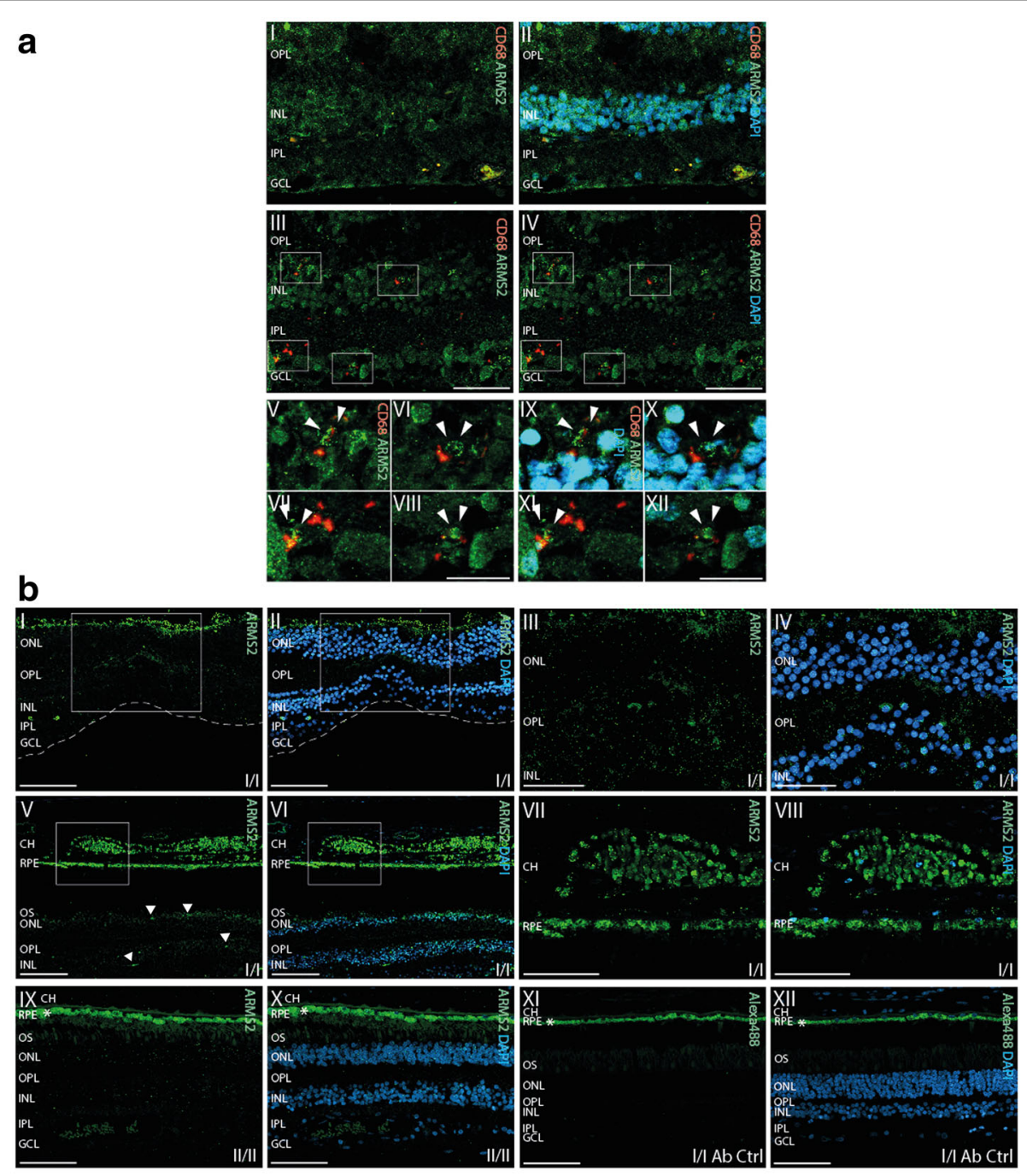

Fig. 2 ARMS2 expression by retinal microglia cells. A I, II Co-labeling of ARMS2 (green) and the macrophage/microglia marker CD68 (red) in the human retina shows co-localization (white arrowheads) of ARMS2 and CD68 indicating ARMS2 expression by retinal microglia cells/macrophages in the human retina. Note that blood monocytes in retinal vessels (dotted lines) co-labeled for ARMS2 and CD68. A II, IV Co-labeling of ARMS2 and CD68 shows that retinal microglia are associated with cells of the inner retina that contain high amounts of ARMS2 on their cell surfaces (white squares). A IV-XII Magnifications of squared areas in (II and IV) show close association of microglia with retinal neurons and strong ARMS2 immunoreactivity (white arrowheads). Left panels (V-VIII) show ARMS2 and CD68. Right panels (A IX-XII) show merged pictures of ARMS2 and CD68 and DAPI. INL inner nuclear layer, IPL inner plexiform layer, GCL ganglion cell layer. Scale bar (A I-IV) $50 \mu \mathrm{m}$; scale bar (A V-XII) $25 \mu \mathrm{m}$. B I, II ARMS2 staining of retinal cross section through the fovea of a human donor with haplotype (I/I). The white squares indicate the area of the macular that is magnified in (B II, IV). B V, VI ARMS2 immunoreactivity in retinal cross section of parafoveal areas obtained from a human donor with haplotype (I/I). The white squares indicate the area of RPE and choroid magnified in (B VII,VIII). ARMS2 staining in the choroid is presumably confined to monocytes and choroidal macrophages, in the retina to microglia cells (arrows) (B IX, X). Retinal cross section from a human donor with haplotype (II/II) that is devoid of ARMS2 immunoreactivity also in the choroid. B XI, XII Control stainings lacking primary antibody. Green autofluorescence lining at the top of the images is derived from RPE (asterisk). Scale bar (B I, II, V, VI, IX, X) 50 um; scale bar (B III, IV, VII, VII, XI, XII) $25 \mu \mathrm{m}$ 
As iPS-derived microglia cells express the ARMS2 gene (Fig. 1a), we aimed to demonstrate ARMS2 expression also for the resident retinal microglia. The surface marker CD68 identified several microglia cells in the cross-section that were ARMS2 positive (Fig. 2A I-IV). The CD68 positive ARMS2 expressing microglia cells were frequently associated with neurons that were highly decorated with ARMS2 (Fig. 2A V-VII). Thus, retinal microglia cells with the genotype I/I very likely express and secrete ARMS2, which then binds to neurons.

\section{ARMS2 binds to cell surfaces}

To further define the role of the ARMS2 protein, we followed up on the observation of ARMS2 deposited on neurons of the retina and investigated whether ARMS2 binds to cell surfaces using flow cytometry. Purified recombinant ARMS2 did not bind to RPE cells (Fig. 3a) or to human erythrocytes (Fig. 3b). To test if ARMS2 binds specifically to modified human surfaces, we measured ARMS2 binding to naïve, apoptotic, or necrotic human $\mathrm{T}$ cells. Apoptotic or necrotic T cells were identified as annexin V and PI positive cells by flow cytometry. In this set up, ARMS2 bound to late apoptotic and necrotic T cells but did not bind to naïve or to early apoptotic T cells (Fig. 3b). This surface attachment is in agreement with the reported ARMS2 binding to extracellular matrix proteins $[2,26]$ and the localization of ARMS2 close to the drusen, which represent accumulated cellular debris as shown by proteome analysis and immune staining [26, 27].

\section{ARMS2 binds to heparan sulfate}

To identify cellular ARMS2 ligands, we studied whether ARMS2 cell surface binding is mediated by surface exposed glycosaminoglycans (GAGs). To this end, we analyzed ARMS2 binding to CHO-K1 (Chinese Hamster Ovary) cells, which expose sulfated GAGs and also to two mutant lines, which lack surface heparan sulfates. ARMS2 bound to wild type CHO-K1 cells but did not bind to the mutant $\mathrm{CHO}_{\text {pgsA }}$ or to $\mathrm{CHO}_{\text {pgsD }}$ cells (Fig. 3d). GAGs represent complex polysaccharides and are exposed at the surface of mammalian cells; GAGs sulfation provides a recognition signal for proteins [28]. To confirm ARMS2 interaction with heparan sulfate in the absence of other cell surface ligands, we studied ARMS2

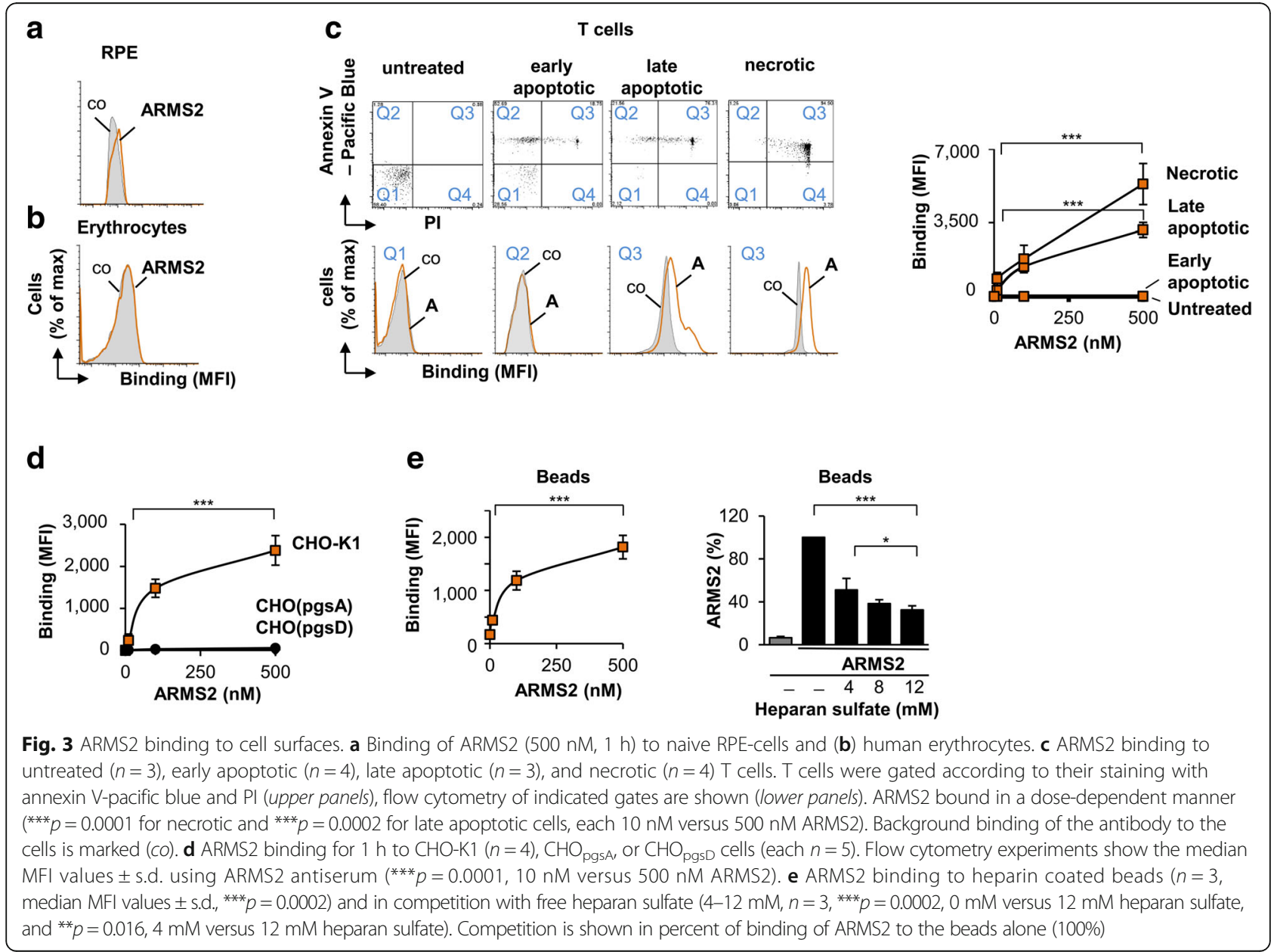


binding to heparin-coated beads. ARMS2 bound to the coated beads, and binding was blocked when ARMS2 was incubated with heparan sulfate prior to binding (Fig. 3e). Thus, ARMS2 binds to cell surfaces via GAGs.

Cell surface bound ARMS2 enhances complement activation Complement is involved in the pathogenesis of AMD as revealed by genetic association studies and also by the presence of complement products in drusen [1, 9, 10, 27]. Given the key role of deregulated complement in AMD pathophysiology, we postulated that ARMS2 influences complement activation. To test this hypothesis, ARMS2 was added to normal human serum (NHS) and this mixture was then added to $\mathrm{CHO}-\mathrm{K} 1$ cells. Following incubation and washing, surface $\mathrm{C} 3 \mathrm{~b}$ deposition was determined by flow cytometry. Addition of NHS to CHO-K1 cells induced complement activation, which was set as $100 \%$. However, ARMS2, when added to NHS, enhanced C3b opsonization of CHO-K1 cells and this effect was dosedependent (Fig. 4a). In contrast, no enhanced C3b
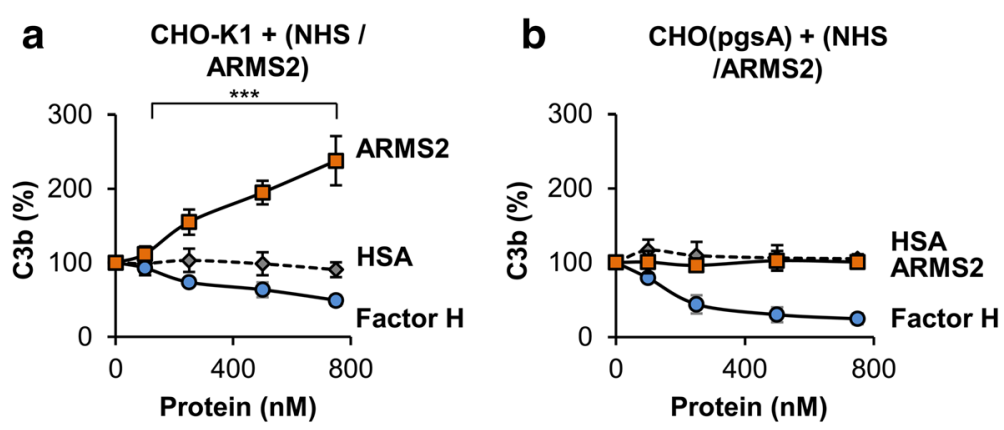

C

(CHO-K1 / ARMS2) + NHS

d

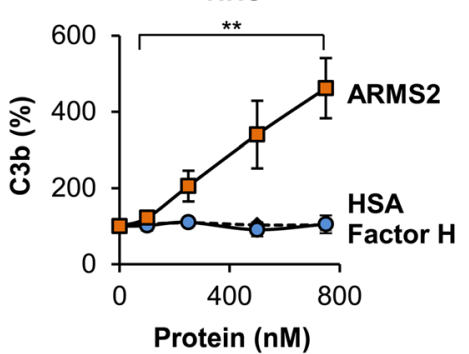

(CHO-K1 / ARMS2) + NHS

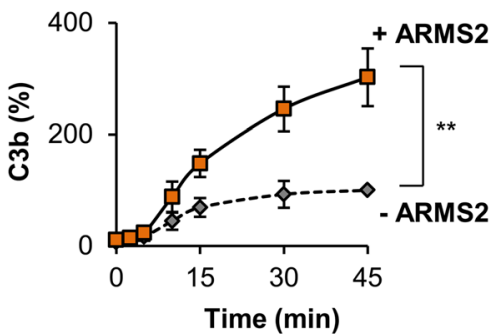

e NHS / ARMS2

f

(CHO-K1 / ARMS2)

+ NHS or hiHS
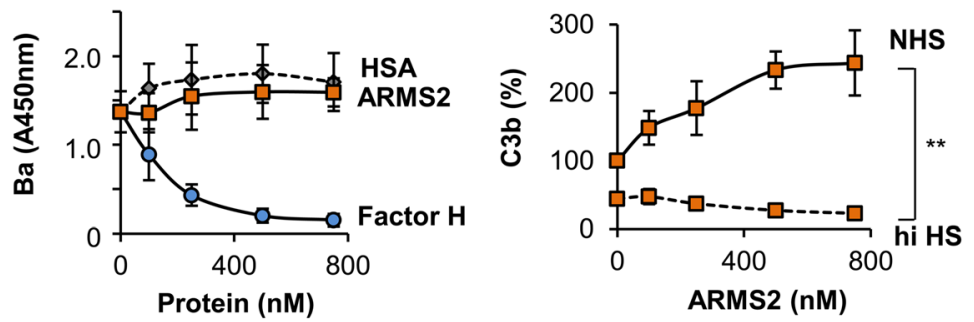

Fig. 4 ARMS2 functions as complement activator on the cell surface. a C3b deposition on CHO-K1 cells is enhanced after incubation for 45 min in 20\% NHS preincubated with ARMS2 (100-750 nM) $\left(n=4,{ }^{* *} p=0.0021,100 \mathrm{nM}\right.$ versus $\left.750 \mathrm{nM}\right)$. Human serum albumin (HSA) had no and factor $\mathrm{H}$ an inhibiting effect on C3b deposition. C3b deposition on cells in NHS alone was set as 100\%. b C3b deposition on $\mathrm{CHO}_{\text {pgsA }}$ cells is not enhanced after incubation in 20\% NHS with ARMS2, factor H or HSA (each 100-750 nM) (each $n=3$ ). C3b deposition on cells in NHS alone was set as 100\%. c Deposition of C3b is increased on ARMS2 (100-750 nM) coated CHO-K1 cells $\left(n=4,{ }^{* *} p=0.0021\right)$ after incubation in 20\% NHS. HSA or factor H does not enhance C3b binding. d ARMS2 (500 nM) attached to CHO-K1 cells and incubated for 45 min in 20\% NHS enhanced C3b deposition over time as compared to cells alone in $20 \%$ NHS (latter was set as 100\%). Error bars show median MFI values \pm s.d. $\left(n=3,{ }^{* *} p=0.0011\right.$, NHS versus NHS + ARMS2). e ARMS2 (100-750 nM) added to 20\% NHS without cells did not enhance Ba generation, as determined by ELISA. Data represent mean values \pm s.d. $(n=3)$. f Deposition of C3b on ARMS2 (100-750 nM) coated CHO-K1 cells is enhanced in 20\% complement active NHS incubated for 45 min but not in heat inactived NHS $\left(30 \mathrm{~min}, 56^{\circ} \mathrm{C}\right)$. Data represent median MFI values \pm s.d. in \% (NHS alone was set as $\left.100 \%\right)\left(n=3,{ }^{* *} p=0.0014\right.$, NHS versus hiHS at $750 \mathrm{nM}$ ARMS2) 
depositon was observed for the mutant line $\mathrm{CHO}_{\text {pgsa }}$ cells that do not bind ARMS2 (Fig. 4b). C3b opsonization was even more pronounced when ARMS2 was attached to the surface of CHO-K1 cells prior to addition of NHS (Fig. 4c), and complement activation was followed over a time period of $45 \mathrm{~min}$. ARMS2 coated to CHO-K1 cells increased C3b deposition by threefold (Fig. 4d) as compared to cells coated with HSA. This increase of C3b surface decoration suggested that ARMS2 attached to a cell surface activates the amplification loop of complement. In contrast to ARMS2, factor $\mathrm{H}$ blocked complement activation in this setup. Remarkably, ARMS2, when added to NHS as a fluid phase protein, did not affect complement activation and in this case, no complement cleavage products like Ba were generated (Fig. 4e). As expected, factor $\mathrm{H}$, when added to NHS in fluid phase, reduced Ba levels. ARMS2 on the surface of $\mathrm{CHO}-\mathrm{K} 1$ and then incubated with heat-inactivated serum (hiHS) did not affect C3b deposition (Fig. 4f). Thus, ARMS2 is a complement activator that acts exclusively on surfaces.

ARMS2 binds the human complement activator properdin To determine how ARMS2 activates complement, binding of ARMS2 to the components of the C3 convertase and to C3 activation products was evaluated. ARMS2 did not bind to $\mathrm{C} 3$, to factor $\mathrm{B}$, or to the cleavage products $\mathrm{C} 3 \mathrm{~b}$, $\mathrm{iC} 3 \mathrm{~b}$, and C3d (Fig. 5a). However, ARMS2 bound to properdin, the only known complement activator [29, 30, 31]. ARMS2 binding to properdin was dose-dependent (Fig. 5b).

To clarify whether ARMS2-properdin complexes recruit $\mathrm{C} 3 \mathrm{~b}$, binding of C3b to preformed ARMS2-properdin complexes was followed. ARMS2 was immobilized to a microtiter plate, properdin was attached, and subsequently, C3b was added. Purified C3b bound to the immobilized ARMS2-properdin complex as determined by ELISA, and binding was dose-dependent (Fig. 5c). Thus, surface-bound ARMS2 binds properdin and subsequently, ARMS2-properdin complexes recruit C3b. These results are in agreement with enhanced $\mathrm{C} 3 \mathrm{~b}$ opsonization when ARMS2 was coated onto CHO-K1 cells prior to challenge with complement active NHS (Fig. 4a). The ARMS2properdin interaction was confirmed by biolayer interferometry. Recombinant ARMS2 was immobilized to a $\mathrm{Ni}^{2+}$ NTA biosensor, and purified properdin was added as analyte. In this set up, properdin bound to immobilized ARMS2 with a $k_{\mathrm{D}}=0.5 \pm 0.07 \times 10^{-6} \mathrm{M}$ (Fig. $5 \mathrm{~d}$ ). In order to localize the domain in ARMS2, that interacts with properdin, three ARMS2 peptides encompassing all amino acids of ARMS2 were coated to a microtiter plate and incubated with properdin. Peptide 3 of ARMS2, but not peptides 1 or 2, showed binding to properdin (Fig. 5e). These results confirm interaction of ARMS2 with properdin and localize the interaction domain in the $\mathrm{C}$-terminal part of ARMS2.
In NHS, properdin exists as trimers or tetramer complexes, and larger complexes are considered artifacts [30]. Therefore, binding of native serum-derived as well as neutrophil-derived properdin was evaluated to ARMS2 coated cells. CHO-K1 cells to which ARMS2 was attached were incubated in complement active NHS or in culture supernatant derived from human neutrophils. Following washing of the cells, ARMS2 and properdin were identified by confocal microscopy (Figs. 5b and 6a). ARMS2 and properdin, either derived from NHS or from supernatant of neutrophils, co-localized on the surface of CHO-K1 cells. Properdin binding to cell surfaces is often C3b dependent [32]. To demonstrate that ARMS2 recruits properdin directly and that ARMS2properdin complexes form in the absence of $\mathrm{C} 3 \mathrm{~b}$, binding of properdin, derived from complement active and inactive NHS, to ARMS2 coated CHO-K1 cells was followed by flow cytometry (Fig. 6c). ARMS2 coated to the cells bound purified properdin. ARMS2 also bound properdin from NHS treated with EGTA, which chelates $\mathrm{Ca}^{2+}$ and inhibits the classical complement pathway but leaves the alternative pathway intact. Also, when EDTA that inhibits $\mathrm{Mg}^{2+}$ and $\mathrm{Ca}^{2+}$ dependent $\mathrm{C} 3$ convertase formation was added to NHS to block C3b generation, properdin bound to surface attached ARMS2. Only when properdin depleted serum was used no properdin, binding to ARMS2 coated CHO-K1 cells was detected (Fig. 6d). Thus ARMS2-properdin complexes are also formed in the absence of C3b. Altogether, the data show that ARMS2 is a surface acting molecule that enhances C3b opsonization via binding of properdin. Thus, microglia cells with the non-risk ARMS2 gene can enhance opsonization and phagocytosis of dead cells by the generation and secretion of ARMS2.

\section{Discussion}

The present study demonstrates expression of ARMS2 in human monocytes as well as in human microglia cells. The ARMS2 expresssion was upregulated in monocytes upon oxidative stress. Deficiency of the ARMS2 protein was observed in monocytes homozygous of the AMD associated genetic polymorphism rs10490924 in the ARMS2 gene. In addition, recombinant ARMS2 binds to surfaces of dead cells and when attached to cellular surfaces, ARMS2 anchors the complement activator properdin. By recruiting and anchoring properdin to cellular surfaces, ARMS2 enhances local complement activation and C3b surface opsonization. C3b/iC3b "tagging" of cells likely facilitates phagocytosis and ultimately removal of cellular debris (Fig. 7). This role of ARMS2 underlines the pivotal role innate immunity plays in retinal homeostasis.

ARMS2 mRNA is expressed in human monocytes and also in stem cell induced human microglia cells, but not in murine macrophages. Expression in human but not in 


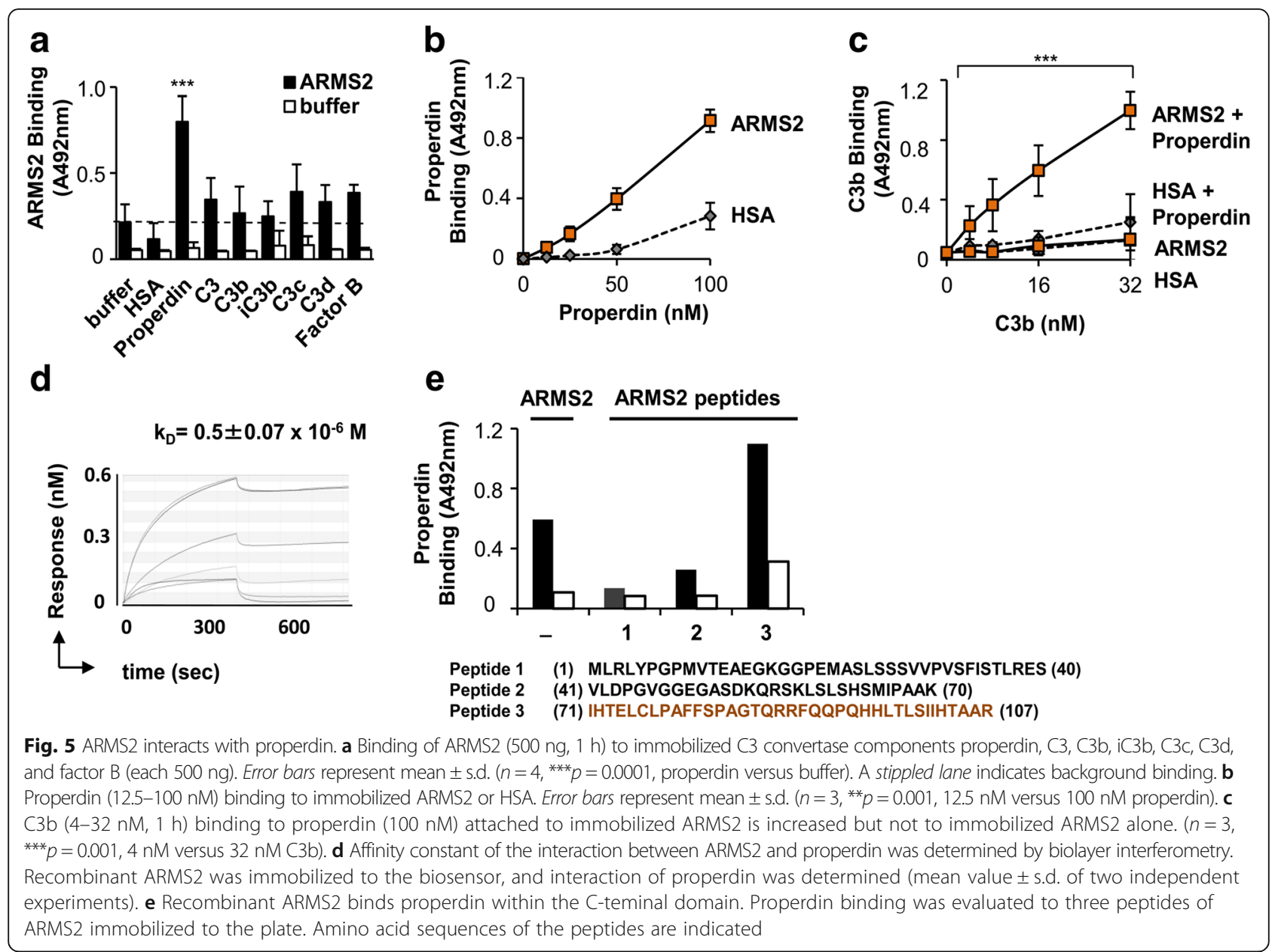

murine cells is in agreement with the relatively late evolutionary appearance of the ARMS2 gene in humans and higher primates [15]. Using a new antiserum, which was generated by immunizing rabbits with recombinant ARMS2 proteins, endogenous ARMS2 protein expression was detected in monocytes derived from individuals with the wild type ARMS2 genotype and also in the human monocytic cell line THP-1, which is heterozygous for the risk ARMS2 haplotype. Similarly, ARMS2 was immunoprecipitated from THP-1 cells with a novel monoclonal ARMS2 antibody. However, the ARMS2 concentration was very low indicating that a trigger is necessary for ARMS2 expression in the cells. Indeed, after blood monocytes were stressed with $\mathrm{H}_{2} \mathrm{O}_{2}$, ARMS2 expression was induced and detected also by Western blotting. Thus, ARMS2 is expressed upon oxidative stress in monocytes and likely also microglia cells, which is in agreement with oxidation specific epitopes on damaged cells in the retina which induce complement activation (3). The recombinant ARMS2 protein, when separated under reducing conditions, appeared as a band with a molecular mass of about $17 \mathrm{kDa}$, which was identified as ARMS2 by mass spectrometry. The whole deglycosylated, untagged recombinant protein showed a mass of $11.349 \mathrm{kDa}$, which is smaller than the calculated mass of $11.4 \mathrm{kDa}$. The difference is explained by pre-treatment of the protein (deglycosylation and removal of the histidine tag). However, deglycosylation of recombinant ARMS2 did not alter binding of ARMS2 to cells or interaction with proteins (data not shown).

ARMS2 gene variations represented by two different polymorphisms, affect ARMS2 protein expression in monocytes. The risk variant represented by polymorphisms rs10490924 is linked with the indel mutation, which affects mRNA stability [12]. The second polymorphism, i.e., rs2736911, which is very rare in homozygous setting in Caucasians but more frequent in individuals of Chinese origin [33], generates a premature stop codon at position 38. Apparently, both polymorphisms rs10490924 and rs2736911 result in ARMS2 protein deficiency as shown in monocytes and retinal section stainings. These results confirm the recent reports demonstrating that the indel mutation in the 3' untranslated region of the $A R M S 2$ gene leads to RNA 


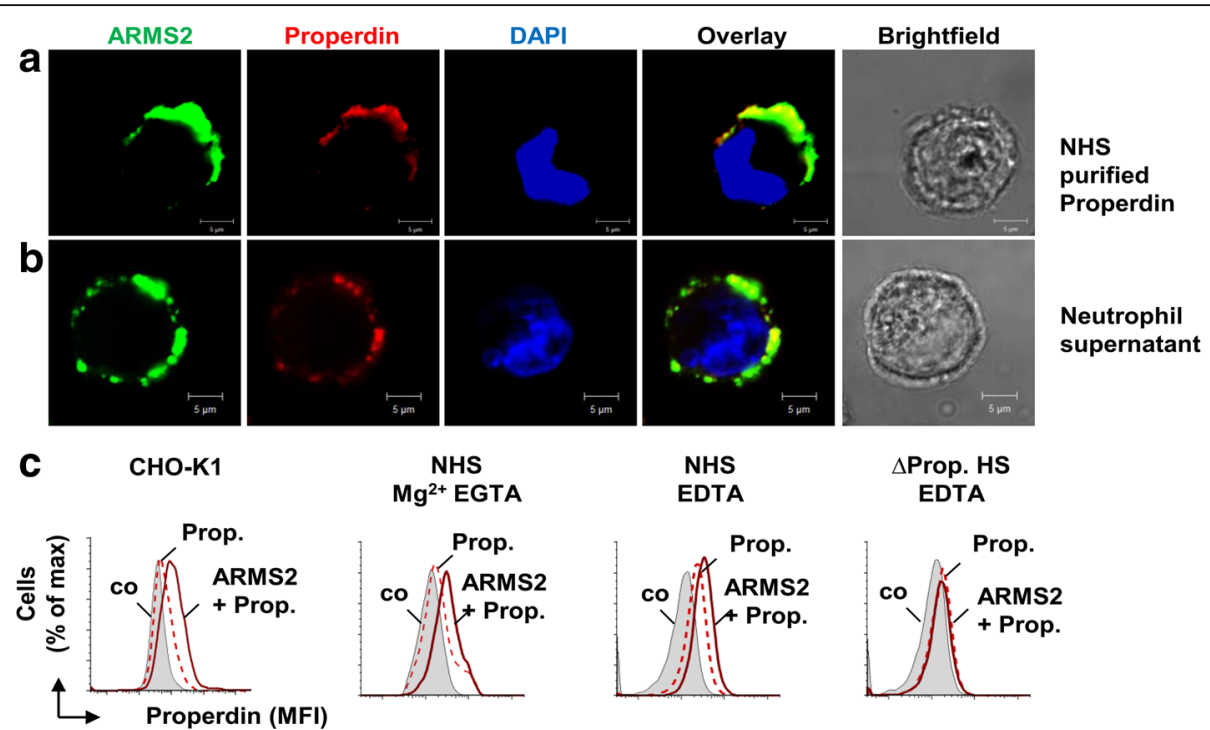

Fig. 6 ARMS2 anchors the human complement activator properdin on cell surfaces. a Co-localization (yellow) of ARMS2 (green) and purified properdin from NHS (red) or (b) properdin from supernatant of human neutrophils (red) on CHO-K1 cells by laser scanning microscopy. Nuclei are stained with DAPI (blue). Scale bar $5 \mu \mathrm{m}$. Representative data from two independent experiments are shown. c Recruitment of purified (left profile) and endogenous properdin to ARMS2 on CHO-K1 cells. ARMS2 was attached to CHO-K1 cells and incubated for $1 \mathrm{~h}$ with purified properdin or in alternative pathway active $\left(\mathrm{Mg}^{2+}\right.$ EGTA), complement inactive (EDTA), or properdin deficient HS as indicated. Properdin binding was determined by flow cytometry. Representative binding profiles of two independent experiments are shown. Background binding of the antibody to the cells is marked (co)

instability $[12,25]$ and ARMS2 protein deficiency in placenta tissue, derived from a person with the ARMS2 risk genotype [12]. These data may help to resolve the contradictory views that exist over ARMS2 as a key effector protein in AMD and on the functional consequences of the polymorphism rs10490924 in ARMS2 [34]. The polymorphism rs10490924 is in strong linkage

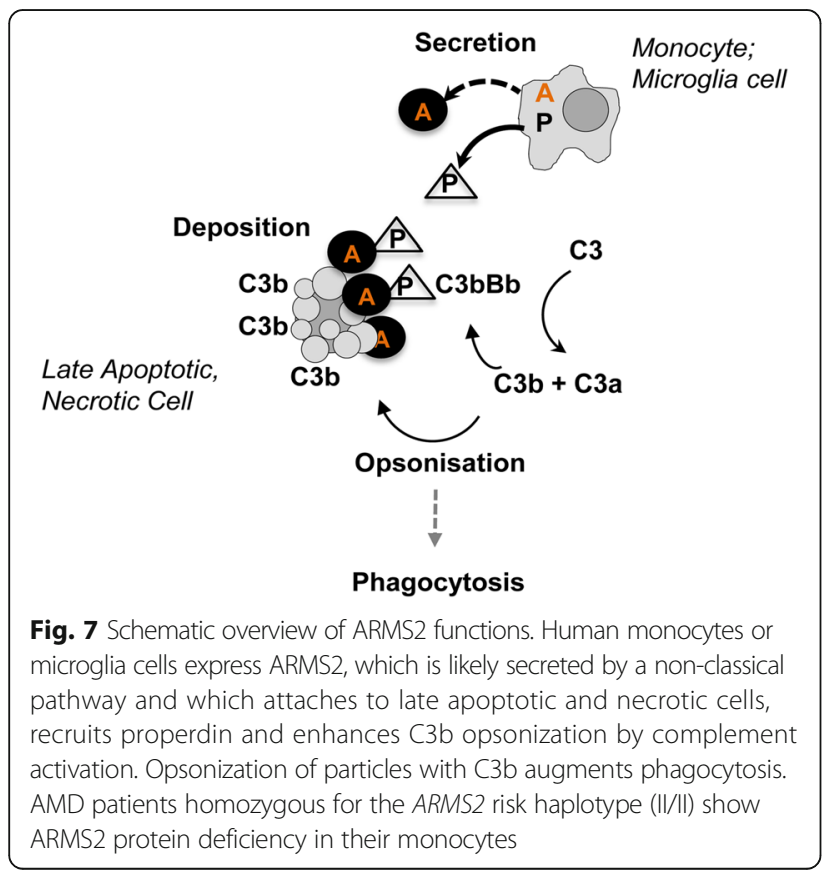

disequilibrium with SNP rs1100638 in the HTRA1 (high temperature requirement factor A1) gene [12, 34, 35] which makes effects by these polymorphisms indistinguishable in statistical analyses.

The innate immune system constantly monitors a spectrum of surfaces, including self, altered self and non-self. Potential targets are recognized on the basis of their characteristic surface molecular patterns. We here demonstrate that the recombinant ARMS2 protein like the complement regulator factor $\mathrm{H}$ binds preferentially to apoptotic and necrotic surfaces and identifies heparan sulfate as an ARMS2 ligand. Interestingly, surface-bound recombinant ARMS2, but not in fluid phase, serves as an anchor for the human complement activator properdin. ARMS2-properdin complexes formed at cellular surfaces enhanced C3 convertase formation and C3 convertases mediated $\mathrm{C} 3 \mathrm{~b}$ opsonization. Such marking of surfaces with C3 cleavage products accelerates recognition, uptake and clearance of debris by human phagocytes [21, 22], and binding of properdin to apoptotic cells enhances this process [28]. Notably, in addition to surface complement activation, complement regulators like factor $\mathrm{H}$ and $\mathrm{C} 4 \mathrm{bp}$ are recruited to the surfaces to restrict the complement cascade and to inhibit inflammation and autoimmune reactions [3, 21, 22].

\section{Conclusions}

The data presented suggest that ARMS2 assists in the clearance of cellular debris in the human retina. Recombinant 
ARMS2 distinguishes certain modified cells via surface glycosaminoglycan structures and initiates complement. Therefore, in case of ARMS2 deficiency complementmediated opsonization, uptake and phagocytosis of dying cells are expected to be impaired. Over a long time, i.e., over years, such a reduced clearance may support accumulation of cellular debris in the retinal space and along Bruch's membrane enhancing formation of drusen, the hallmark of AMD.

\section{Additional file}

Additional file 1: Figure S1. Expression vector with ARMS2 coding sequence. (PDF $268 \mathrm{~kb}$ )

\section{Abbreviations}

AMD: Age-related macular degeneration; ARMS2: Age-related maculopathy susceptibility 2; FACS: Fluorescence-activated cell sorting; iPSdM: Induced pluripotent stem cell-derived microglia; LSM: Laser scanning microscopy; PCR: Polymerase chain reaction

\section{Acknowledgements}

The authors thank all German AMD patients for their participation. We also thank Maria Pötsch (Leibniz Institute for Natural Product Reseach and Infection Biology, Jena) for MS analyses.

\section{Funding}

This research was supported by the German Council "Deutsche Forschungs-Gemeinschaft" SK46, Zi432, LA1206, the "Pro Retina" foundation and the Thuringian Ministry of Science and Education, Germany. HN is a member of the DFG-funded excellence cluster ImmunoSensation (EXC 1023). YL is a doctoral researcher at the International Leibniz Research School (ILRS), part of the Jena school of Microbial Communication (JSMC).

\section{Availability of data and materials}

Materials are available at christine.skerka@hki-jena.de.

\section{Authors' contributions}

CS conceptualized this study, CS and PFZ wrote the manuscript and interpreted all results. SM, YL, H-MD, MA, and $\mathrm{MvH}$ performed protein expression, functional assays, microscopy, sequencing, surface plasmon resonance, and discussed data. PD, SL, and LS analyzed gene expression in monocytes. BHW and FG provided ARMS2 expression vectors. HN, TL, and MK generated, analyzed, provided iPSdM cells, and performed immunohistochemistry of human retinas. DP generated the ARMS2 mAb. AMJ and SJ recruited and evaluated subjects and provided blood samples. SF provided and analyzed retinal sections from human donor eyes. All authors approved and commented on it.

\section{Competing interests}

The authors declare that they have no competing interests.

\section{Consent for publication}

Not applicable.

\section{Ethics approval and consent to participate}

All research conducted followed the tenets of the Declaration of Helsinki. The local ethics committee of the University of Cologne has approved the study under No. 14-247 and the Institutional Review Board of the Charité Berlin, Germany under study protocol No. EA2/004/2014.

\section{Author details}

'Department of Infection Biology, Leibniz Institute for Natural Product Research and Infection Biology, Beutenbergstrasse 11, 07745 Jena, Germany. ${ }^{2}$ Department of Ophthalmology, Charité Universitätsmedizin Berlin, Augustenburger Platz 1, 13353 Berlin, Germany. ${ }^{3}$ Laboratory for Experimental Immunology of the Eye, Department of Ophthalmology, University of Cologne, Joseph-Stelzmann-Str. 9, 50931 Cologne, Germany. ${ }^{4}$ Institute of
Nutrition, Friedrich Schiller University Jena, Dornburger Str. 25, 07743 Jena, Germany. ${ }^{5}$ Institute of Human Genetics, University of Regensburg, Franz-Josef-Strauß-Allee 11, 93053 Regensburg, Germany. Institute of Reconstructive Neurobiology, University of Bonn, Sigmund-Freud-Str. 25, 53127 Bonn, Germany. ${ }^{7}$ Department of Ophthalmology, University Hospital Regenburg, Franz-Josef-Strauß-Allee 11, 93053 Regensburg, Germany.

${ }^{8}$ Friedrich Schiller University, Fürstengraben, 07743 Jena, Germany.

Received: 28 September 2015 Accepted: 9 December 2016

Published online: 05 January 2017

\section{References}

1. Ambati J, Atkinson JP, Gelfand BD. Immunology of age-related macular degeneration. Nat Rev Immunol. 2013;13:438-51.

2. Wang G, Spencer KL, Scott WK, Whitehead P, Court BL, Ayala-Haedo J, Mayo P, Schwartz SG, Kovach JL, Gallins P, Polk M, Agarwal A, Postel EA, Haines JL, Pericak-Vance MA. Analysis of the indel at the ARMS2 3'UTR in age-related macular degeneration. Hum Genet. 2010;127:595-602.

3. Weismann D, Hartvigsen K, Lauer N, Bennett KL, Scholl HP, Charbel Issa P, Cano M, Brandstätter H, Tsimikas S, Skerka C, Superti-Furga G, Handa JT, Zipfel PF, Witztum $J$, Binder CJ. Complement factor $\mathrm{H}$ binds malondialdehyde epitopes and protects from oxidative stress. Nature. 2010;478:76-81.

4. Lauer N, Mihlan M, Hartmann A, Schlötzer-Schrehardt U, Keilhauer C, Scholl HP, Charbel Issa P, Holz F, Weber BH, Skerka C, Zipfel PF. Complement regulation at necrotic cell lesions is impaired by the age-related macular degenerationassociated factor-H His402 risk variant. J Immunol. 2011;187:4374-83.

5. Raychaudhuri S, lartchouk O, Chin K, Tan PL, Tai AK, Ripke S, Gowrisankar S, Vemuri S, Montgomery K, Yu Y, Reynolds R, Zack DJ, Campochiaro B, Campochiaro P, Katsanis N, Daly MJ, Seddon JM. A rare penetrant mutation in CFH confers high risk of age-related macular degeneration. Nat Genet. 2011:43:1232-6

6. Van de Ven JP, Nilsson SC, Tan PL, Buitendijk GH, Ristau T, Mohlin FC, Nabuurs SB, Schoenmaker-Koller FE, Smailhodzic D, Campochiaro PA, Zack DJ, Duvvari MR, Bakker B, Paun CC, Boon CJ, Uitterlinden AG, Liakopoulos S, Klevering BJ, Fauser S, Daha MR, Katsanis N, Klaver CC, Blom AM, Hoyng CB, den Hollander Al. A functional variant in the CFI gene confers a high risk of age-related macular degeneration. Nat Genet. 2013;45:813-7.

7. Montes T, Tortajada A, Morgan BP, Rodríguez de Córdoba S, Harris CL. Functional basis of protection against age-related macular degeneration conferred by a common polymorphism in complement factor B. Proc Natl Acad Sci U S A. 2013;106:4366-71.

8. Zhan X, Larson DE, Wang C, Koboldt DC, Sergeev W, Fulton RS, Fulton LL, Fronick CC, Branham KE, Bragg-Gresham J, Jun G, Hu Y, Kang HM, Liu D, Othman M, Brooks M, Ratnapriya R, Boleda A, Grassmann F, von Strachwitz C, Olson LM, Buitendijk GH, Hofman A, van Duijn CM, Cipriani V, Moore AT, Shahid H, Jiang Y, Conley YP, Morgan DJ, Kim IK, Johnson MP, Cantsilieris S, Richardson AJ, Guymer $\mathrm{RH}$, Luo H, Ouyang H, Licht C, Pluthero FG, Zhang MM, Zhang K, Baird PN, Blangero J, Klein ML, Farrer LA, DeAngelis MM, Weeks DE, Gorin MB, Yates JR, Klaver CC, Pericak-Vance MA, Haines JL, Weber BH, Wilson R, Heckenlively JR, Chew EY, Stambolian D, Mardis ER, Swaroop A, Abecasis GR. Identification of a rare coding variant in complement 3 associated with age-related macular degeneration. Nat Genet. 2013;45:1375-9.

9. Zipfel PF, Skerka C. Complement regulators and inhibitory proteins. Nat Rev Immunol. 2009;9:729-40.

10. Ricklin D. Manipulating the mediator: modulation of the alternative complement pathway C3 convertase in health, disease and therapy. Immunobiol. 2012;217:1057-66.

11. Zipfel PF, Lauer N, Skerka C. The role of complement in AMD. Adv Exp Med Biol. 2010;703:9-24.

12. Fritsche $L G$, Loenhardt $T$, Janssen A, Fisher SA, Rivera A, Keilhauer CN, Weber $\mathrm{BH}$. Age-related macular degeneration is associated with an unstable ARMS2 (LOC387715) mRNA. Nat Genet. 2008;40:892-6.

13. Fritsche $L G$ and the AMD Gene Consortium. Seven new loci associated with age-related macular degeneration. Nat Genet. 2013;45:433-9.

14. Kanda A, Chen W, Othman M, Branham KE, Brooks M, Khanna R, He S, Lyons R, Abecasis GR, Swaroop A. A variant of mitochondrial protein LOC387715/ARMS2, not HTRA1, is strongly associated with age-related macular degeneration. Proc Natl Acad Sci U S A. 2007;104:16227-32.

15. Francis PJ, Appukuttan B, Simmons E, Landauer N, Stoddard J, Hamon S, Ott $J$, Ferguson B, Klein M, Stout JT, Neuringer M. Rhesus monkeys and humans 
share common susceptibility genes for age-related macular disease. Hum Mol Genet. 2008;17:2673-80.

16. Spencer KL, Olson LM, Anderson BM, Schnetz-Boutaud N, Scott WK, Gallins P, Agarwal A, Postel EA, Pericak-Vance MA, Haines JL. C3 R102G polymorphism increases risk of age-related macular degeneration. Hum Mol Genet. 2008;17:1821-4.

17. Beutner C, Roy K, Linnartz B, Napoli I, Neumann H. Generation of microglial cells from mouse embryonic stem cells. Nat Protoc. 2010;5:1481-94.

18. Heinen S, Hartmann A, Lauer N, Wiehl U, Dahse HM, Schirmer S, Gropp K, Enghardt T, Wallich R, Hälbich S, Mihlan M, Schlötzer-Schrehardt U, Zipfel PF, Skerka C. Factor H-related protein 1 (CFHR-1) inhibits complement C5 convertase activity and terminal complex formation. Blood. 2009;114:2439-47.

19. Eberhardt HU, Buhlmann D, Hortschansky P, Chen Q, Böhm S, Kemper MJ, Wallich R, Hartmann A, Hallström T, Zipfel PF, Skerka C. Human factor Hrelated protein 2 (CFHR2) regulates complement activation. PLoS One. 2013; 8:e78617.

20. Pauly D, Nagel BM, Reinders J, Killian T, Wulf M, Ackermann S, Ehrenstein B, Zipfel PF, Skerka C, Weber BH. A novel antibody against human properdin inhibits the alternative complement system and specifically detects properdin from blood samples. PLoS One. 2014;9:e96371. doi:10.1371/ journal.pone.0096371.

21. Trouw LA, Blom AM, Gasque P. Role of complement and complement regulators in the removal of apoptotic cells. Mol Immunol. 2008:45:1199-207.

22. Elkon KB, Silverman GJ. Naturally occurring autoantibodies to apoptotic cells. Adv Exp Med Biol. 2012;750:14-26.

23. Penfold PL, Madigan MC, Gillies MC, Provis JM. Immunological and aetiological aspects of macular degeneration. Prog Retin Eye Res. 2001;20: 385-414.

24. Weigelt K, Ernst W, Walczak Y, Ebert S, Loenhardt T, Klug M, Rehli M, Weber BH, Langmann T. Dap12 expression in activated microglia from retinoschisin-deficient retina and its PU.1-dependent promoter regulation. J Leukoc Biol. 2007;82:1564-74.

25. Friedrich U, Myers CA, Fritsche LG, Milenkovich A, Wolf A, Corbo JC, Weber $\mathrm{BH}$. Risk- and non-risk-associated variants at the 10q26 AMD locus influence ARMS2 mRNA expression but exclude pathogenic effects due to protein deficiency. Hum Mol Genet. 2011;20:1387-99.

26. Kortvely E, Hauck SM, Duetsch G, Gloeckner CJ, Kremmer E, Alge-Priglinger CS, Deeg CA, Ueffing M. ARMS2 is a constituent of the extracellular matrix providing a link between familial and sporadic age-related macular degenerations. Invest Ophthalmol Vis Sci. 2010;51:79-88.

27. Crabb JW, Miyagi M, Gu X, Shadrach K, West KA, Sakaguchi H, Kamei M, Hasan A, Yan L, Rayborn ME, Salomon RG, Hollyfield JG. Drusen proteome analysis: an approach to the etiology of age-related macular degeneration. Proc Natl Acad Sci U S A. 2002;99:14682-7.

28. Langford-Smith A, Keenan TD, Clark SJ, Bishop PN, Day AJ. The role of complement in age-related macular degeneration: heparan sulphate, a ZIP code for complement factor H? J Innate Immun. 2014;6:407-16.

29. Xu W, Berger SP, Trouw LA, de Boer HC, Schlagwein N, Mutsaers C, Daha $\mathrm{MR}$, van Kooten C. Properdin binds to late apoptotic and necrotic cells independently of $\mathrm{C} 3 \mathrm{~b}$ and regulates alternative pathway complement activation. J Immunol. 2008;180:7613-21.

30. Kemper C, Mitchell LM, Zhang L, Hourcade DE. The complement protein properdin binds apoptotic $\mathrm{T}$ cells and promotes complement activation and phagocytosis. Proc Natl Acad Sci U S A. 2008;105:9023-8.

31. Cortes C, Ohtola JA, Saggu G, Ferreira VP. Local release of properdin in the cellular microenvironment: role in pattern recognition and amplification of the alternative pathway of complement. Front Immunol. 2013;3:412. doi:10. 3389/fimmu.2012.00412. eCollection 2012.

32. Lesher AM, Nilsson B, Song WC. Properdin in complement activation and tissue insury. Mol Immunol. 2013;56:191-8.

33. Yu W, Dong S, Zhao C, Wang H, Dai F, Yang J. Cumulative association between age-related macular degeneration and less studied genetic variants in PLEKHA1/ARMS2/HTRA1: a meta and gene-cluster analysis. Mol Biol Rep. 2013;40:5551-61.

34. Fritsche LG, IgI W, Bailey JN, Grassmann F, Sengupta S, Bragg-Gresham JL, Burdon KP, Hebbring SJ, Wen C, Gorski M, Kim IK, Cho D, Zack D, Souied E, Scholl HP, Bala E, Lee KE, Hunter DJ, Sardell RJ, Mitchell P, Merriam JE, Cipriani V, Hoffman JD, Schick T, Lechanteur YT, Guymer RH, Johnson MP, Jiang Y, Stanton CM, Buitendijk GH, Zhan X, Kwong AM, Boleda A, Brooks M, Gieser L, Ratnapriya R, Branham KE, Foerster JR, Heckenlively JR, Othman MI, Vote BJ, Liang HH, Souzeau E, McAllister IL, Isaacs T, Hall J, Lake S, Mackey
DA, Constable IJ, Craig JE, Kitchner TE, Yang Z, Su Z, Luo H, Chen D, Ouyang H, Flagg K, Lin D, Mao G, Ferreyra H, Stark K, von Strachwitz CN, Wolf A, Brandl C, Rudolph G, Olden M, Morrison MA, Morgan DJ, Schu M, Ahn J, Silvestri G, Tsironi EE, Park KH, Farrer LA, Orlin A, Brucker A, Li M, Curcio CA, Mohand-Saïd S, Sahel JA, Audo I, Benchaboune M, Cree AJ, Rennie CA, Goverdhan SV, Grunin M, Hagbi-Levi S, Campochiaro P, Katsanis N, Holz FG, Blond F, Blanché H, Deleuze JF, Igo Jr RP, Truitt B, Peachey NS, Meuer SM, Myers CE, Moore EL, Klein R, Hauser MA, Postel EA, Courtenay MD, Schwartz SG, Kovach JL, Scott WK, Liew G, Tan AG, Gopinath B, Merriam JC, Smith RT, Khan JC, Shahid H, Moore AT, McGrath JA, Laux R, Brantley Jr MA, Agarwal A, Ersoy L, Caramoy A, Langmann T, Saksens NT, de Jong EK, Hoyng CB, Cain MS, Richardson AJ, Martin TM, Blangero J, Weeks DE, Dhillon B, van Duijn CM, Doheny KF, Romm J, Klaver CC, Hayward C, Gorin MB, Klein ML, Baird PN, den Hollander Al, Fauser S, Yates JR, Allikmets R, Wang JJ, Schaumberg DA, Klein BE, Hagstrom SA, Chowers I, Lotery AJ, Léveillard T, Zhang K, Brilliant MH, Hewitt AW, Swaroop A, Chew EY, Pericak-Vance MA, DeAngelis M, Stambolian D, Haines JL, lyengar SK, Weber BH, Abecasis GR, Heid IM. A large genome-wide association study of age-related macular degeneration highlights contributions of rare and common variants. Nat Genet. 2016:48:134-43.

35. Allikmets R, Dean M. Bringing age-related macular degeneration into focus. Nat Genet. 2008:40:820-1.

\section{Submit your next manuscript to BioMed Central and we will help you at every step:}

- We accept pre-submission inquiries

- Our selector tool helps you to find the most relevant journal

- We provide round the clock customer support

- Convenient online submission

- Thorough peer review

- Inclusion in PubMed and all major indexing services

- Maximum visibility for your research

Submit your manuscript at www.biomedcentral.com/submit
( Biomed Central 